\title{
DIETARY INTAKE OF MINERALS AND PROSTATE CANCER: INSIGHTS INTO PROBLEM BASED ON THE CHEMICAL ELEMENT CONTENTS IN THE PROSTATE GLAND
}

\author{
V. Zaichick', S. Zaichick ${ }^{1,2}$
}

\begin{abstract}
Objective: As men age total dietary mineral bioavailability falls which may increase the risk of prostate cancer. The aims of this study were to investigate the changes in main mineral contents in prostate gland that occurred with aging. Design: Population based study on changes in mineral contents in prostate gland with ageing. Participants and setting: 65 free-living healthy men aged 21-87 years who had died suddenly. Prostates were removed at necropsy and the samples of morphologic normal prostate tissue were investigated. Measurements: Contents of ten main minerals ( $\mathrm{B}, \mathrm{Ca}, \mathrm{Co}, \mathrm{Cr}, \mathrm{Cu}, \mathrm{Fe}, \mathrm{Mg}$, Mn, Se, and $\mathrm{Zn}$ ) were determined by four instrumental analytical methods. Results: No any age-related deficiencies in minerals such as B, Ca, Co, Cr, Cu, Fe, Mg, Mn, Se, and $\mathrm{Zn}$ in the prostate tissue were found. Moreover, the mean mass fractions of $\mathrm{Co}, \mathrm{Fe}$, and $\mathrm{Zn}$ in prostate tissue for the age group adult men aged 41 years and older were statistically significant higher than for those younger than 40 years. Conclusions: Ageing is not associated with reduced mineral contents in prostate gland resulting in inadequate intakes in nutrients. Nutrition policy for men aged 41 years and older should include advice to decrease intakes of red meat for the purpose to reduce Fe and $\mathrm{Zn}$ intake.
\end{abstract}

Key words: Minerals intakes, aging, free-living men, minerals in prostate tissue, prostate cancer risk.

Abbreviations: PCa: Prostate Cancer; ROS: Reactive Oxygen Species; B: Boron; Ca: Calcium; Co: Cobalt; Cr: Chromium; Cu: Copper; Fe: Iron; Mg: Magnesium; Mn: Manganese; Se: Selenium; Zn: Zinc; RCTs: Randomized Controlled Trials; CRM: Certified Reference Material; EDXRF: Energy-Dispersive X-Ray Fluorescent analysis; INAA-SLR: Instrumental Neutron Activation Analysis with high resolution spectrometry of Short-Lived Radionuclides; INAA-LLR: Instrumental Neutron Activation Analysis with high resolution spectrometry of Long-Lived Radionuclides; ICP-AES: Inductively Coupled Plasma Atomic Emission Spectrometry.

\section{Introduction}

Prostate cancer (PCa) is the second most common cause of male cancer-related deaths and the most common male non-cutaneous malignancy in the Western world (1). PCa is the fourth most common type of cancer worldwide (2). According to epidemiological data the greatest risk factor for prostate cancer is increasing age. The prevalence of prostate cancer drastically increases with age, being three orders of magnitude higher for the age group 40-79 years than for those younger than 39 years $(3,4)$. To date, we still have no precise knowledge of the biochemical processes underlying the etiology and pathogenesis of PCa. There are a few hypotheses on the

1. Radionuclide Diagnostics Department, Medical Radiological Research Centre, Korolyev Str. 4, Obninsk 249036, Kaluga Region, Russia; 2. Current address: Department of Medicine, University of Illinois College of Medicine, Chicago, IL 60612, USA.

Corresponding Author: Prof. Dr. V. Zaichick, Medical Radiological Research Centre, Korolyev Str. 4, Obninsk 249036, Kaluga Region, Russia, Phone: (48439) 60289, Fax: (495) 956 1440, E-mail: vezai@obninsk.com

subject. Among these hypotheses the possible role of the oxidative stress, which increased with age, has been noted in the literature $(5,6)$.

Reactive oxygen species (ROS) are widely considered to be a causal factor not only in aging but in a number of pathological conditions, including carcinogenesis. Aging, considered as an impairment of body functions over time, caused by the accumulation of molecular damage in DNA, proteins and lipids, is also characterized by an increase in intracellular oxidative stress due to the progressive decrease of the intracellular ROS scavenging (5). Oxidative damage to cellular macromolecules which induce cancer can also arise through overproduction of ROS and faulty antioxidant and/or DNA repair mechanisms (7). Overproduction of ROS is associated with inflammation, radiation, and other factors, including overload of some chemical elements, in both blood and certain tissues, or deficiency in chemical elements with antioxidant properties (8-11). Studies have shown that the imbalance in the composition of chemical elements may cause different types of pathology. The importance 
of appropriate levels of many chemical elements is indisputable, due to their beneficial roles when in specific concentration ranges, while on the other hand they can cause toxic effects with excessively high or low concentrations (12-19).

Dozens of epidemiologic and biochemical (chemical element contents in blood, hair, and nails) studies have looked at potential connections between mineral intakes or status and PCa risk. A list of these minerals included $\mathrm{B}, \mathrm{Ca}, \mathrm{Mg}$, Se and transition metals such as $\mathrm{Co}, \mathrm{Cr}$, $\mathrm{Cu}, \mathrm{Fe}, \mathrm{Mn}, \mathrm{Zn}$ (2, 20-31). Unfortunately, data on the effects of mineral intake on PCa risk are inconsistent and present a very mixed picture. Some studies provide evidence of a positive association, while others report an inverse proportion or no association. On the one hand, there is evidence of mineral bioavailability decreases in the elderly (32). Proponents of "theory of deficiency" think that due to lifestyle, eating and dietary habits, and physiological effects of aging, the elderly male population is normally predisposed to conditions of $\mathrm{Cu}, \mathrm{Fe}, \mathrm{Mn}, \mathrm{Se}$, $\mathrm{Zn}$ and other antioxidant deficiency, which can increase their susceptibility to $\mathrm{PCa}(22,33,34)$. On the other hand, dozens of epidemiologic studies have looked at potential connections between PCa risk and mineral overloads resulting from excessive use of dairy foods (major source of $\mathrm{Ca}$ ), red meet (major source of Fe and $\mathrm{Zn}$ ), and mineral supplements (Ca, Mg, Fe, Zn, Se and others) (20, 27, 31, 35).

Since most studies reported to date are case-control analyses, there remain more questions than evidencebased data. It is generally accepted that the long-term randomized controlled trials (RCTs) can highlighting the unanswered question (36). However, such RCTs are extremely difficult. They must be conducted for decades to detect effects on long-latency disease incidence, such as $\mathrm{PCa}$, and compliance is difficult to maintain (37). In our opinion, one valuable and relatively simple way to elucidate the situation is to compare the mass fractions of minerals in prostate tissue of young adult (the norm) with those in adult and geriatric prostate. Carcinogenesis is considered to occur in four stages: initiation, promotion, progression, and metastasis. Thus, the findings of the excess or deficiency in minerals and the perturbation in their relationships in nonhyperplastic prostate glands of adult and elderly males may highlight the role of these disturbances at list in two stages of carcinogenesis: initiation and promotion.

The data on age-dependence of chemical element mass fractions in adult and geriatric nonhyperplastic prostate is apparently extremely limited (38-40). Moreover, the majority of these data are based on measurements of processed tissue. In several studies tissue samples are ashed before analysis. In other cases, prostate samples are treated with solvents (distilled water, ethanol etc) and then are dried at high temperature for many hours. There is evidence that certain quantities of minerals are lost as a result of such treatment $(41,42)$. In addition, only a few of these studies employed quality control using certified reference materials (CRM) for determination of the chemical element mass fractions.

The primary purpose of this study was to determine valid values for mass fraction of minerals in the nonhyperplastic prostate of subjects of different age from young adult to elderly persons using four analytical methods: an energy dispersive X-ray fluorescence (EDXRF), an instrumental neutron activation analysis with high resolution spectrometry of short-lived (INAA-SLR) and long-lived (INAA-LLR) radionuclides, and an inductively coupled plasma atomic emission spectrometry (ICP-AES). The second aim was to evaluate the quality of obtained results for mass fraction of minerals. The final aim was to compare the chemical element mass fractions in prostate gland of age group 2 (adult and elderly persons, who were aged $\geq 41$ years), with those of group 1 (adults aged 21 to 40 years).

All studies were approved by the Ethical Committee of the Medical Radiological Research Center, Obninsk.

\section{Materials and Methods}

Samples of the human prostate were obtained from randomly selected autopsy specimens of 65 males (European-Caucasian) aged 21 to 87 years. Age ranges for subjects were divided into two age groups, with group 1, 21-40 years (30.4 \pm 1.1 years, $\mathrm{M} \pm \mathrm{SEM}, \mathrm{n}=28)$ and group 2, 41-87 years (54.8 \pm 10.9 years, $\mathrm{M} \pm S E M, n=37$ ). These groups were selected to reflect the condition of prostate tissue in the first period of adult life (group 1 ) and in the second period of adult life and in old age (group 2). The available clinical data were reviewed for each subject. None of the subjects had a history of an intersex condition, endocrine disorder, neoplasm or other chronic disease that could affect the normal development of the prostate. None of the subjects were receiving medications and mineral supplements known to affect prostate morphology or chemical element content. The typical causes of death of most of these patients included acute illness (cardiac insufficiency, stroke, embolism of pulmonary artery, alcohol poisoning) and trauma. All prostate glands were divided (with an anterior-posterior cross-section) into two portions using a titanium scalpel. One tissue portion was reviewed by an anatomical pathologist while the other was used for the chemical element content determination. Only the posterior part of the prostate, including the transitional, central, and peripheral zones, was investigated. A histological examination was used to control the age norm conformity as well as to confirm the absence of any microadenomatosis and/or latent cancer.

After the samples intended for chemical element analysis were weighed, they were freeze-dried and homogenized. The pounded sample weighing about $8 \mathrm{mg}$ was applied to a piece of adhesive tape, which served as a sample backing for EDXRF analysis. The 
Table 1

EDXRF, NAA-SLR, and NAA-LLR data $\mathrm{Ca}, \mathrm{Mg}$, Se, and Zn contents in the IAEA H-4 (animal muscle) reference material compared to certified values $(\mathrm{mg} / \mathrm{kg}$, dry mass basis)

\begin{tabular}{|c|c|c|c|c|c|c|c|}
\hline Element & \multicolumn{4}{|c|}{ Certified values } & \multicolumn{3}{|c|}{$\begin{array}{c}\text { This work results } \\
\mathrm{M} \pm \mathrm{SD} \text { (10 subsamples) }\end{array}$} \\
\hline $\mathrm{Ca}$ & 188 & & $163-213$ & $\mathrm{C}$ & - & $238 \pm 59$ & - \\
\hline Co & 0.0027 & & - & $\mathrm{N}$ & - & - & $0.0034 \pm 0.0008$ \\
\hline $\mathrm{Fe}$ & 49.1 & & $42.6-55.6$ & $\mathrm{C}$ & $48 \pm 9$ & - & $47.0 \pm 1.0$ \\
\hline $\mathrm{Mg}$ & 1050 & & $990-1110$ & $\mathrm{C}$ & - & $1100 \pm 190$ & - \\
\hline $\mathrm{Mn}$ & 0.52 & & $0.48-0.55$ & $\mathrm{~N}$ & - & $0.55 \pm 0.11$ & - \\
\hline Se & 0.28 & & $0.20-0.36$ & $\mathrm{C}$ & - & - & $0.281 \pm 0.014$ \\
\hline
\end{tabular}

$\mathrm{M}$ arithmetic mean, SD standard deviation, $\mathrm{C}$ certified values, $\mathrm{N}$ non-certified values

Table 2

ICP-AES data of chemical element contents in Certified Reference Materials (M $\pm S D, \mathrm{mg} / \mathrm{kg}$, dry mass basis)

\begin{tabular}{|c|c|c|c|c|c|c|}
\hline \multirow[t]{2}{*}{ Element } & \multicolumn{2}{|c|}{ Soya Bean Flour (INCT-SBF-4) } & \multicolumn{2}{|c|}{ Tea Leaves (INCT-TL-1) } & \multicolumn{2}{|c|}{$\begin{array}{c}\text { Mixed Polish Herbs (IN- } \\
\text { CT-MPH-2) }\end{array}$} \\
\hline & Certificate & $\begin{array}{l}\text { This work } \\
\text { result }\end{array}$ & Certificate & $\begin{array}{l}\text { This work } \\
\text { result }\end{array}$ & Certificate & $\begin{array}{c}\text { This work } \\
\text { result }\end{array}$ \\
\hline B & $39.9 \pm 4.0$ & $34.5 \pm 1.4$ & $26 a$ & $24.8 \pm 1.2$ & - & $28.8 \pm 8.1$ \\
\hline $\mathrm{Ca}$ & $2467 \pm 170$ & $2737 \pm 190$ & $5820 \pm 520$ & $6296 \pm 360$ & $10800 \pm 700$ & $10250 \pm 294$ \\
\hline $\mathrm{Fe}$ & $90.8 \pm 4.0$ & $80.5 \pm 6.9$ & $432 a$ & $493 \pm 39$ & $460 \mathrm{a}$ & $459 \pm 33$ \\
\hline $\mathrm{Mg}$ & $3005 \pm 82$ & $2983 \pm 340$ & $2240 \pm 170$ & $2415 \pm 115$ & $2920 \pm 180$ & $2955 \pm 159$ \\
\hline Mn & $32.3 \pm 1.1$ & $30.0 \pm 1.0$ & $1570 \pm 110$ & $1628 \pm 145$ & $191 \pm 12$ & $197 \pm 5$ \\
\hline $\mathrm{Zn}$ & $52.3 \pm 1.3$ & $54.8 \pm 6.6$ & $34.7 \pm 2.7$ & $36.0 \pm 3.7$ & $33.5 \pm 2.1$ & $32.0 \pm 6.1$ \\
\hline
\end{tabular}

$\mathrm{M}$ arithmetic mean, SD standard deviation, a Informative values

sample weighing about $100 \mathrm{mg}$ was used for chemical element measurement by instrumental NAA-SLR. The samples for INAA-SLR were sealed separately in thin polyethylene films washed with acetone and rectified alcohol beforehand. The sealed samples were placed in labeled polyethylene ampoules. The sample weighing about $50 \mathrm{mg}$ was used for chemical element measurement by instrumental NAA-LLR. The samples for NAA-LLR were wrapped separately in a high-purity aluminum foil washed with rectified alcohol beforehand and placed in a nitric acid-washed quartz ampoule. The samples weighing about $100 \mathrm{mg}$ for ICP-AES were decomposed in autoclaves: $1.5 \mathrm{~mL}$ of concentrated $\mathrm{HNO} 3$ (nitric acid at $65 \%$, maximum of $0.0000005 \% \mathrm{Hg}$; GR, ISO, Merck) and $0.3 \mathrm{~mL}$ of $\mathrm{H} 2 \mathrm{O} 2$ (pure for analysis) were added to prostate tissue samples and then they were heated for 3 $\mathrm{h}$ at $160-200{ }^{\circ} \mathrm{C}$. After autoclaving, samples were cooled to room temperature and solutions from the decomposed samples were diluted with deionized water (up to $20 \mathrm{~mL}$ ) and transferred to plastic measuring bottles.

For quality control, samples of the certified reference materials IAEA H-4 Animal muscle from the International Atomic Energy Agency (IAEA), and also samples INCT-SBF-4 Soya Bean Flour, INCT-TL-1 Tea Leaves and INCT-MPH-2 Mixed Polish Herbs from the Institute of Nuclear Chemistry and Technology (INCT, Warszawa, Poland) were analyzed simultaneously with the investigated prostate tissue samples. All samples of CRMs were treated in the same way as the prostate tissue samples.

The mass fractions of Fe and $\mathrm{Zn}$ were measured by EDXRF, the mass fractions of $\mathrm{Ca}, \mathrm{Mg}$, and $\mathrm{Mn}-$ by NAA-SLR, the mass fractions of $\mathrm{Co}, \mathrm{Cr}, \mathrm{Fe}, \mathrm{Se}$, and $\mathrm{Zn}$ - by NAA-LLR, and the mass fractions of $\mathrm{B}, \mathrm{Ca}, \mathrm{Cu}, \mathrm{Fe}$, $\mathrm{Mg}, \mathrm{Mn}$, and $\mathrm{Zn}$ - by ICP-AES. Details of the analytical methods and procedures used here such as nuclear 
reactions, radionuclides, gamma-energies, wavelength, spectrometers, spectrometer parameters and operating conditions were presented in our earlier publications concerning the chemical elements of human prostate gland (43-49).

A dedicated computer program of INAA mode optimization was used (50). Using the Microsoft Office Excel program the arithmetic mean, standard deviation, and standard error of mean were calculated for all the chemical element mass fractions obtained. For elements investigated by two or more methods the mean of all results was used. The reliability of difference in the results between two age groups was evaluated by Student's parametric t-test. For the construction of diagrams the Microsoft Office Excel program was also used.

\section{Results}

Table 1 presents our data for $\mathrm{Ca}, \mathrm{Co}, \mathrm{Cr}, \mathrm{Fe}, \mathrm{Mg}, \mathrm{Mn}$, $\mathrm{Se}$, and $\mathrm{Zn}$ mass fraction ( $\mathrm{mg} / \mathrm{kg}$, dry mass basis) in ten sub-samples of CRM IAEA H-4 (animal muscle) determined by EDXRF, NAA-SLR, and NAA-LLR as well as the certified values of this material.

\section{Figure 1}

Individual data sets for the $\mathrm{B}, \mathrm{Ca}, \mathrm{Co}, \mathrm{Cr}, \mathrm{Cu}, \mathrm{Fe}, \mathrm{Mg}, \mathrm{Mn}$, $\mathrm{Se}$, and $\mathrm{Zn}$ mass fraction in the prostate gland of males between ages $21-87$ years

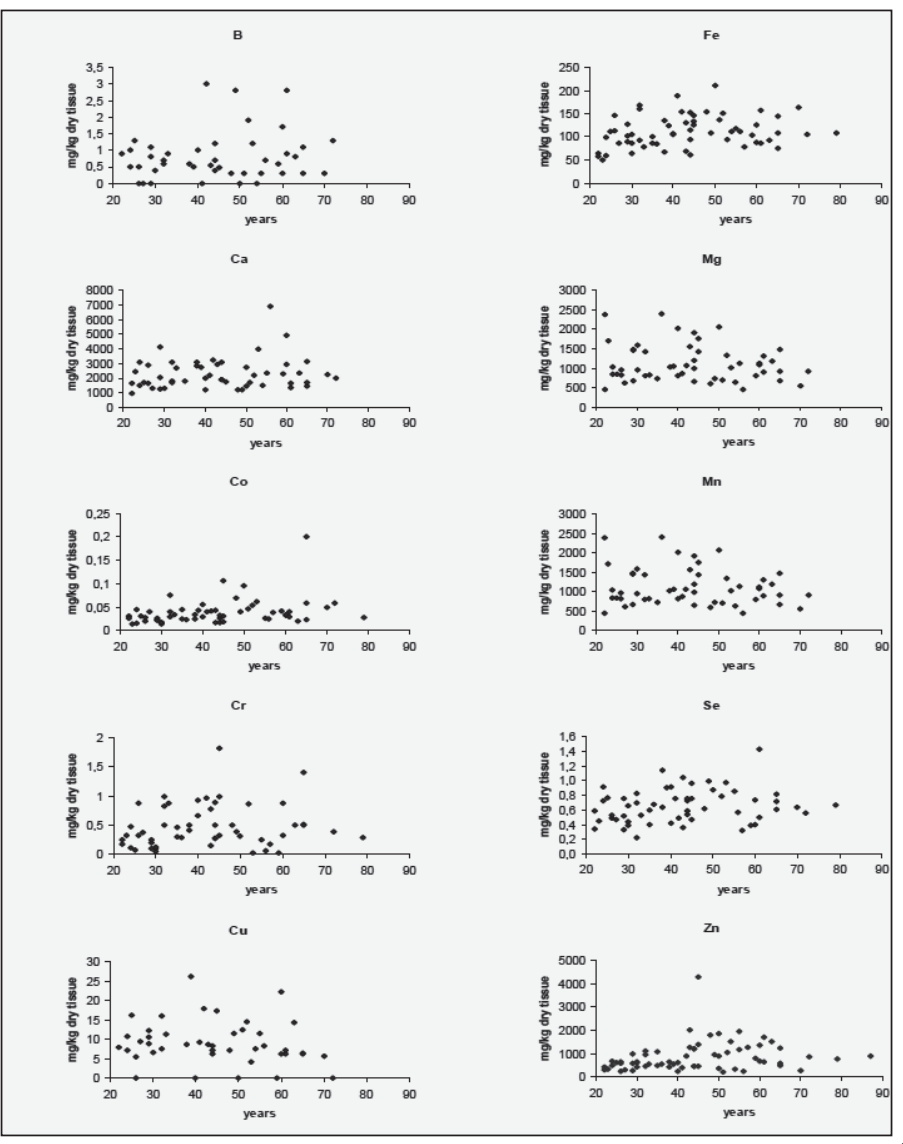

Figure 2

Arithmetic mean \pm standard error of mean $(\mathrm{M} \pm \mathrm{SEM})$ of $\mathrm{B}, \mathrm{Ca}, \mathrm{Co}, \mathrm{Cr}, \mathrm{Cu}, \mathrm{Fe}, \mathrm{Mg}$, $\mathrm{Mn}$, Se, and $\mathrm{Zn}$ mass fractions $(\mathrm{mg} / \mathrm{kg}$, dry mass basis) in prostate glands of age group 1 (21-40 years) and 2 (41-87 years)

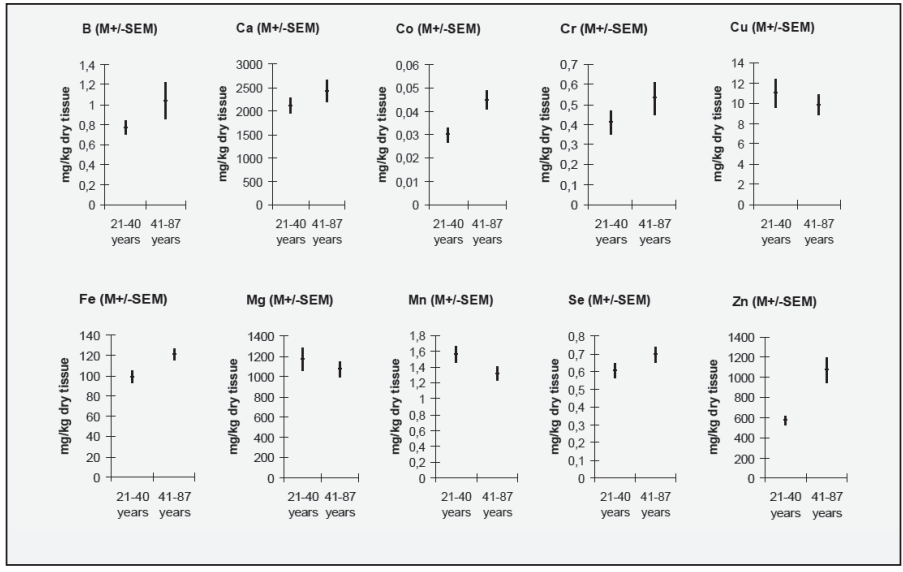

Table 2 depicts the results obtained by ICP-AES for $\mathrm{B}, \mathrm{Ca}, \mathrm{Cu}, \mathrm{Fe}, \mathrm{Mg}, \mathrm{Mn}$, and $\mathrm{Zn}$ mass fraction $(\mathrm{mg} /$ $\mathrm{kg}$, dry mass basis) in ten sub-samples of three CRMs: INCT-SBF-4 (Soya Bean Flour), INCT-TL-1 (Tea Leaves), and INCT-MPH-2 (Mixed Polish Herbs), as well as the certified values of these materials.

Table 3 summarizes the results obtained for mass fractions of 10 minerals (arithmetic mean \pm standard deviation, $\mathrm{M} \pm \mathrm{SD}, \mathrm{mg} / \mathrm{kg}$, dry mass basis) in nonhyperplastic prostate glands of males in the age ranges 21-87 years measured by means of the four analytical methods described above.

Figure 1 shows individual data sets for the $\mathrm{B}, \mathrm{Ca}, \mathrm{Co}$, $\mathrm{Cr}, \mathrm{Cu}, \mathrm{Fe}, \mathrm{Mg}, \mathrm{Mn}, \mathrm{Se}$, and $\mathrm{Zn}$ mass fraction $(\mathrm{mg} / \mathrm{kg}$, dry mass basis) in the nonhyperplastic prostate gland of males in the age range $21-87$ years.

To analyze the effect of age on the mineral mass fractions in the prostate we examined the two age groups, described above. Figure 2 shows our data for arithmetic mean \pm standard error of mean $(\mathrm{M} \pm \mathrm{SEM})$ of $\mathrm{B}, \mathrm{Ca}, \mathrm{Co}$, $\mathrm{Cr}, \mathrm{Cu}, \mathrm{Fe}, \mathrm{Mg}, \mathrm{Mn}$, Se, and $\mathrm{Zn}$ mass fractions $(\mathrm{mg} / \mathrm{kg}$, dry mass basis) in prostate glands of age group 1 (21-40 years) and 2 (41-87 years). The ratios of means and the reliability of difference between mean values of mineral mass fraction in the age group 1 and 2 are presented in Table 4.

\section{Discussion}

The fact that the elemental mass fractions $(\mathrm{M} \pm \mathrm{SD})$ of the certified reference materials obtained in the present work were in good agreement with the certified values and within the corresponding 95\% confidence intervals (Tables 1 and 2) suggests an acceptable accuracy of the measurements performed on prostate tissue samples.

The use of four analytical methods allowed us to estimate the mass fractions of 10 most important minerals 
Table 3

Arithmetic means $(\mathrm{M} \pm \mathrm{SD}$ ) of the $\mathrm{B}, \mathrm{Ca}, \mathrm{Co}, \mathrm{Cr}, \mathrm{Cu}, \mathrm{Fe}, \mathrm{Mg}, \mathrm{Mn}$, Se, and $\mathrm{Zn}$ mass fractions (mg/ $\mathrm{kg}$, dry mass basis) in nonhyperplastic prostate glands of males between ages $21-87$ years $(n=65)$ obtained by means of four analytical methods

\begin{tabular}{|c|c|c|c|c|c|}
\hline Element & EDXRF & NAA-SLR & NAA-LLR & ICP-AES & Derived value \\
\hline $\mathrm{Ca}$ & - & $2150 \pm 802$ & - & $2292 \pm 1052$ & $2285 \pm 1066$ \\
\hline Co & - & - & $0.038 \pm 0.022$ & - & $0.038 \pm 0.022$ \\
\hline $\mathrm{Cr}$ & - & - & $0.47 \pm 0.37$ & - & $0.47 \pm 0.37$ \\
\hline $\mathrm{Cu}$ & - & - & - & $10.3 \pm 4.9$ & $10.3 \pm 4.9$ \\
\hline $\mathrm{Mg}$ & - & $1149 \pm 484$ & - & $1052 \pm 412$ & $1115 \pm 472$ \\
\hline Mn & - & $1.45 \pm 0.44$ & - & $1.38 \pm 0.35$ & $1.42 \pm 0.45$ \\
\hline Se & - & - & $0.65 \pm 0.23$ & - & $0.65 \pm 0.23$ \\
\hline $\mathrm{Zn}$ & $928 \pm 628$ & - & $795 \pm 573$ & $844 \pm 759$ & $856 \pm 634$ \\
\hline
\end{tabular}

M arithmetic mean; SD standard deviation; EDXRF energy dispersive X-ray fluorescence; NAA-SLR neutron activation analysis with high resolution spectrometry of short-lived radionuclides; NAA-LLR neutron activation analysis with high resolution spectrometry of long-lived radionuclides; ICP-AES nductively coupled plasma atomic emission spectrometry; Derived value for elements investigated by two or more methods the mean of all results was used.

in nonhyperplastic adult and geriatric prostate glands of males in the age ranges $21-87$ years. Good agreement (Table 3) was found between the results obtained with non-destructive (EDXRF, NAA-SLR, and NAA-LLR) and destructive method (ICP-AES) for all minerals indicating complete digestion of the prostate samples (for ICP-AES technique) and correctness of all results obtained by the various methods (Table 3 ).

In the histologically normal prostates, we have observed an increase (more than 10\%) in mass fraction of $\mathrm{B}, \mathrm{Ca}, \mathrm{Co}, \mathrm{Cr}, \mathrm{Fe}, \mathrm{Se}$, and $\mathrm{Zn}$ with age from 21 to 87 years (Figs. 1 and 2, Table 4). In particular, a significant tendency of age-related increase in Co $(p \leq 0.004), \mathrm{Fe}$ $(p \leq 0.009)$, and $Z n(p \leq 0.0004)$ mass fraction was observed in prostate (Table 4). For example, in prostate in group 2 the $\mathrm{Zn}$ mass fractions was almost 2 times greater than in prostate of members of group 1 (Fig. 2, Table 4).

The variations of the individual mass fractions of many minerals increased with age. It followed from the qualitative analysis of individual data sets (Fig. 1) and the quantitative comparison of the values of relative standard deviations (M/SD, \%) in the age group 1 and 2 (Fig. 2), for example, for B (35\% v $83 \%)$, Ca (38\% v 51\%), and $\mathrm{Zn}(41 \% \mathrm{v} 73 \%)$. Of course, individual variation of dietary, environmental, occupational, medicamental, and some other factors impact on an accumulation of minerals in the prostate within the lifespan. In addition, in our previous studies it was shown that many minerals bind tightly with one of the histological structures of prostate glands such as stroma, epithelial cells, and glandular lumen (51-55). It was also found that the per cent volumes of these histological structures depend from age and the individual uroflowmetric characteristics of the subject (56). Moreover, the variations of the individual per cent volumes of histological structures and uroflowmetric characteristics increased also with age (51$56)$.

\section{Table 4}

Ratio of mean values and the reliability of difference between mean values of chemical element mass fractions in nonhyperplastic prostate glands of males of age group 1 (21-40 years) and 2 (41-87 years)

\begin{tabular}{lll}
\hline Element & $\begin{array}{l}\text { Ratio of means } \\
\text { M2/M1 }\end{array}$ & $\begin{array}{l}\text { M1 and M2 } \\
\text { Student's t-test, } \mathbf{p} \leq\end{array}$ \\
\hline $\mathrm{B}$ & 1.35 & 0.173 \\
$\mathrm{Ca}$ & 1.24 & 0.278 \\
$\mathrm{Co}$ & 1.53 & $\mathbf{0 . 0 0 4}$ \\
$\mathrm{Cr}$ & 1.31 & 0.211 \\
$\mathrm{Cu}$ & 0.96 & 0.497 \\
$\mathrm{Fe}$ & 1.22 & $\mathbf{0 . 0 0 9}$ \\
$\mathrm{Mg}$ & 0.94 & 0.469 \\
$\mathrm{Mn}$ & 0.85 & 0.092 \\
$\mathrm{Se}$ & 1.06 & 0.131 \\
$\mathrm{Zn}$ & 1.99 & $\mathbf{0 . 0 0 0 4}$ \\
\hline
\end{tabular}

M1,2 arithmetic mean in age group 1 and 2, respectively; Statistically significant values of $\mathrm{p}$ are in bold.

This work's results for age-dependence of minerals in adult and geriatric nonhyperplastic prostate glands (20-87 years) are in accordance with earlier findings for $\mathrm{Ca}, \mathrm{Cu}$, and $\mathrm{Zn}$ (38-40). For example, Heinzsch et al. (38) found that the $\mathrm{Zn}$ mass fraction in the normal prostate was higher in the age group 51-70 years than in the age group 31-50 years by approximately 1.8 times. 
Multiple studies put forward an idea that due to lifestyle, dietary habits, and physiological effects of aging, the elderly male population is predisposed to $\mathrm{B}, \mathrm{Ca}, \mathrm{Cu}$, $\mathrm{Fe}, \mathrm{Mg}, \mathrm{Se}, \mathrm{Zn}$ and some other mineral deficiencies (8, $28,32-34,57,58)$, which can increase this population's susceptibility to PCa $(8,22,28)$. Our data reveal that there are no any age-related deficiencies in minerals investigated in the prostate tissue. Moreover, the mean mass fractions of $\mathrm{Co}, \mathrm{Fe}$, and $\mathrm{Zn}$ for the age group adult males aged 41 years and older are statistically significant higher than for those younger than 40 years. Thus, "the potential role of age-related deficiency $\mathrm{B}, \mathrm{Ca}, \mathrm{Cu}, \mathrm{Fe}, \mathrm{Mg}$, $\mathrm{Se}, \mathrm{Zn}$ " $(8,22,28)$ or other main minerals in the prostate has not been confirmed as being involved in the etiology of PCa.

Adult prostatic mean $\mathrm{Zn}$ levels increase from $570 \mathrm{mg} /$ $\mathrm{kg}$ (dry mass basis) in group 1 (21-40 years) to 1072 $\mathrm{mg} / \mathrm{kg}$ in group 2 (41-87 years). The normal level of $\mathrm{Zn}$ mass fraction in the prostate tissue of young adults is higher than mean values of this element's content in all other soft and hard tissues of human body (47-49, 59-61). Excessive prostatic tissue $\mathrm{Zn}$ level in the older males may be harmful to normal metabolism of cells (62) and partially responsible for an age-related enlargement of the prostate. In humans, $\mathrm{Zn}$ intake is positively correlated with circulating levels of insulin-like growth factor-I (63) and testosterone (64) that are both directly related to the proliferation of prostate cell (65). By now much data has been obtained that is related both to the direct and indirect action of $\mathrm{Zn}$ on the DNA polymeric organisation, replication and lesions, and to its vital role for cell division (66-68). Moreover, it is known that $\mathrm{Zn}$ is an inhibitor of the Ca-dependent apoptotic endonuclease, which takes part in the internucleosomal fragmentation of DNA. Its consequence is a depression of cell apoptosis (69). Some other ways for $\mathrm{Zn}$ to act as a potent antiapoptotic agent have also been described (70-73). All these facts imply that age-related excessive $\mathrm{Zn}$ level in prostatic tissue are probably one of the main factors influencing enlargement of the prostate and the initiation and promotion stages of PCa.

In addition to the elevated Zn level, an age-related increase and excess in $\mathrm{Co}$ and $\mathrm{Fe}$ mass fractions in prostatic tissue may contribute to the harmful effect on the gland. There are good reasons for such speculations about $\mathrm{Fe}$ since several reviews and many papers raise the concern about carcinogenicity of this metal overload (74-78). It was also shown that cobalt may be human carcinogen, but the experimental and epidemiologic data are limited (79-81). Our finding implies that an age-related increase and excess in $\mathrm{Co}, \mathrm{Fe}$, and $\mathrm{Zn}$ mass fraction in prostatic tissue may be one of the main factors in the etiology PCa. Red meat is the major source of Fe and $\mathrm{Zn}$ in foodstuff. Thus, nutrition policy for men aged 41 years and older should include advice to decrease intakes of red meat for the purpose to reduce $\mathrm{Fe}$ and $\mathrm{Zn}$ intake. This advice agrees well with many epidemiological evidences of positive correlation between red meat intake and PCa risk $(35,82,83)$.

\section{Conclusion}

Our data reveal that there are no any age-related deficiencies in minerals such as $\mathrm{B}, \mathrm{Ca}, \mathrm{Co}, \mathrm{Cr}, \mathrm{Cu}, \mathrm{Fe}, \mathrm{Mg}$, $\mathrm{Mn}, \mathrm{Se}$, and $\mathrm{Zn}$ in the prostate tissue. Thus, "the potential role of age-related deficiency $\mathrm{B}, \mathrm{Ca}, \mathrm{Cu}, \mathrm{Fe}, \mathrm{Mg}$, Se, $\mathrm{Zn}$ " or other minerals in the prostate has not been confirmed as being involved in the etiology of PCa. Moreover, the mean mass fractions of $\mathrm{Co}, \mathrm{Fe}$, and $\mathrm{Zn}$ for the age group adult men aged 41 years and older are statistically significant higher than for those younger than 40 years. It implies that an age-related increase and excess in $\mathrm{Co}, \mathrm{Fe}$, and $\mathrm{Zn}$ mass fraction in prostatic tissue may be one of the main factors in the etiology PCa. Red meat is the major source of $\mathrm{Fe}$ and $\mathrm{Zn}$ in foodstuff. Thus, nutrition policy for men aged 41 years and older should include advice to decrease intakes of red meat for the purpose to reduce Fe and $\mathrm{Zn}$ intake.

Acknowledgments: The authors are grateful to the late Prof. A.A. Zhavoronkov, Institute of Human Morphology, Russian Academy of Medical Sciences, Moscow, for supplying prostate specimens. We are also grateful to Dr. Karandaschev V., Dr. Nosenko S., and Moskvina I., Institute of Microelectronics Technology and High Purity Materials, Chernogolovka, Russia, for their help in ICP-AES analysis.

Financial disclosure: None of the authors had any financial interest or support for this paper.

Conflicts of interest: Authors have declared that no conflicts of interest exist.

Ethical standard: All studies were approved by the Ethical Committee of the Medical Radiological Research Center, Obninsk.

\section{References}

1. Velonas VM, Woo HH, Remedios CG, Assinder SJ. Current status of biomarkers for prostate cancer. Int J Mol Sci 2013;14:11034-11060

2. Vogt TM, Ziegler RG, Graubard BI, Swanson CA, Greenberg RS, Schoenberg JB, Swanson GM, Hayes RB, Mayne ST. Serum selenium and risk of prostate cancer in U.S. blacks and whites. Int J Cancer 2003;103:664-670

3. Jemal A, Murray T, Samuels A, Ghafoor A, Ward E, Thun M J. Cancer statistics, 2003. CA Cancer J Clin 2003;53:5-26

4. Rebbeck TR. Conquering cancer disparities: new opportunities for cancer epidemiology, biomarker, and prevention research. Cancer Epidemiol Biomarkers Prev 2006;15:1569-1571

5. Minelli A, Bellezza I, Conte C, Culig Z. Oxidative stress-related aging: A role for prostate cancer? Biochim Biophys Acta 2009;1795:83-91

6. Przybyszewski WM, Rzeszowska-Wolny J. Oxidative stress in prostate hypertrophy and carcinogenesis. Postepy Hig Med Dosw 2009;63:340-350

7. Klaunig JE, Kamendulis LM, Hocevar BA. Oxidative stress and oxidative damage in carcinogenesis. Toxicol Pathol 2010;38:96-109

8. Sapota A, Darago A, Taczalski J, Kilanowicz A. Disturbed homeostasis of zinc and other essential elements in the prostate gland dependent on the character of pathological lesions. Biometals 2009;22:1041-1049. doi: 10.1007/ s10534-009-9255-y

9. Henkler F, Brinkmann J, Luch A. The role of oxidative stress in carcinogenesis induced by metals and xenobiotics. Cancers (Basel) 2010;2:376-396. doi: 10.3390/ cancers2020376

10. Jomova K, Valko M. Advances in metal-induced oxidative stress and human disease. Toxicology 2011;283:65-87. doi: 10.1016/j.tox.2011.03.001

11. Lee J.-C., Son Y.-O., Pratheeshkumar P., Shi X. Oxidative stress and metal carcinogenesis. Free Radical Biology \& Medicine 2012;53:742-757. doi:10.1016/j.freeradbiomed.2012.06.002

12. Zaichick V, Zaichick S. Role of zinc in prostate cancerogenesis. In: Mengen und Spurenelemente. 19. Arbeitstagung. Friedrich-Schiller-Universitat, Jena, pp 1999;104-115

13. Zaichick V, Zaichick S. Age-related histological and zinc content changes in adult nonhyperplastic prostate glands. Age 2014;36:167-181 
14. Järup . Hazards of heavy metal contamination. Br Med Bull 2003;68:167-182

15. Zaichick V. INAA and EDXRF applications in the age dynamics assessment of $\mathrm{Zn}$ content and distribution in the normal human prostate. J Radioanal Nucl Chem 2004;262:229-234

16. Zaichick V. Medical elementology as a new scientific discipline. J Radioanal Nucl Chem 2006;269:303-309

17. Toyokuni S. Molecular mechanisms of oxidative stress-induced carcinogenesis: from epidemiology to oxygenomics. IUBMB Life 2008;60(7):441-447

18. Gupte A, Mumper RJ. Elevated copper and oxidative stress in cancer cells as a target for cancer treatment. Cancer Treat Rev 2009;35:32-46

19. Lee JD, Wu SM, Lu LY, Yang YT, Jeng SY. Cadmium concentration and metallothionein expression in prostate cancer and benign prostatic hyperplasia of humans. J Formos Med Assoc 2009;108:554-559

20. Leitzmann MF, Stampfer MJ, Wu K, Colditz GA, Willett WC, Giovannucci EL. Zinc Supplement Use and Risk of Prostate Cancer. J Natl Cancer Inst 2003;95:1004-1007

21. Cui Y, Winton MI, Zhang ZF, Rainey C, Marshall J, De Kernion JB Eckhert CD. Dietary boron intake and prostate cancer risk. Oncol Rep Apr 2004;11:887-892

22. Costello LC, Franklin RB, Feng P, Tan M, Bagasra O. Zinc and prostate cancer: a critical scientific, medical, and public interest issue (United States). Cancer Causes Control 2004;16:901-915

23. Barranco W, Hudak P, Eckhert C. Evaluation of ecological and in vitro effects of boron on prostate cancer risk. Cancer Causes Control 2007;18:71-77. doi:10.1007/s10552-006-0077-8

24. Skinner HG, Schwartz GG. Serum calcium and incident and fatal prostate cancer in the National Health and Nutrition Examination Survey. Cancer Epidemiol Biomarkers Prev 2008;17:2302-2305. doi: 10.1158/1055-9965.EPI08-0365

25. Williams CD, Whitley BM, Hoyo C, Grant DJ, Schwartz GG, Presti JC Jr, Iraggi JD, Newman KA, Gerber L, Taylor LA, McKeever MG, Freedland SJ. Dietary calcium and risk for prostate cancer: a case-control study among US veterans. Prev Chronic Dis 2012;9:110125. doi: http://dx.doi.org/10.5888/ pcd9.110125

26. Adedapo KS, Arinola OG, Shittu OB, Kareem OI, Okolo CA, Nwobi LN Diagnostic value of lipids, total antioxidants, and trace metals in benign prostate hyperplasia and prostate cancer. Niger J Clin Pract 2012;15:293-297. doi: 10.4103/1119-3077.100623

27. Aslam R, Neubauer S. Dairy foods, milk, calcium, and risk of prostate cancer. Oncology Nutrition Connection 2013;21:3-10

28. Nielsen FH. Update on human health effects of boron. J Trace Elem Med Biol 2014;28:383-387. doi: 10.1016/j.jtemb.2014.06.023

29. Qayyum MA, Shah MH. Comparative study of trace elements in blood, scalp hair and nails of prostate cancer patients in relation to healthy donors. Biol Trace Elem Res 2014;162:46-57. DOI 10.1007/s12011-014-0123-4

30. Henderson KA, Kobylewski SE, Yamada KE, Eckhert CD. Boric acid induces cytoplasmic stress granule formation, $\mathrm{eIF} 2 \mathrm{O} \pm$ phosphorylation, and ATF4 in prostate DU-145 cells. BioMetals 2015;28:133-141

31. Lin PH, Aronson W, Freedland SJ. Nutrition, dietary interventions and prostate cancer: the latest evidence. MC Med 2015;13:3. doi: 10.1186/s12916014-0234-y.

32. Vaquero MP. Magnesium and trace elements in the elderly: intake, status and recommendations. J Nutr Health Aging 2002;6:147-153

33. Mocchegiani E, Muaaioli M, Giacconi R. Zinc, metallothioneins, immune responses, survival and ageing. Biogeront 1:133-143

34. Ekmekcioglu C. The role of trace elements for the health of elderly individuals. Nahrung 2001;45:309-316

35. Mandair D, Rossi RE, Pericleous M, Whyand T, Caplin ME. Prostate cancer and the influence of dietary factors and supplements: a systematic review. Nutr Metab (Lond) 2014;11:30. doi: 10.1186/1743-7075-11-30.

36. National Institutes of Health State-of-the-Science Panel. National Institutes of Health State-of-the-Science Conference Statement: multivitamin/ mineral supplements and chronic disease prevention. Am J Clin Nutr 2007:85(suppl):257S-264S

37. Ames BN, McCann JC, Stampfer MJ, Willett WC. Evidence-based decision making on micronutrients and chronic disease: long-term randomized controlled trials are not enough. Am J Clin Nutr 2007;86:522-523

38. Hienzsch E, Schneider H-J, Anke M. Vergleichende Untersuchungen zum Mengen- und Spurenelementgehalt der normalen Prostata, des Prostataadenoms und des Prostatakarzinoms. Z Urol Nephrol 1970;63:543546

39. Leissner KM, Fielkegard B, Tisell LE. Concentration and content of zinc in human prostate. Invest Urol 1980;18:32-35

40. Tohno S, Kobayashi M, Shimizu H, Tohno Y, Suwannahoy P, Azuma C, Minami T, Sinthubua A, Mahakkanukrauh P. Age-related changes of the concentrations of select elements in the prostates of Japanese. Biol Trace Elem Res 2009;127:211-227

41. Zaichick V. Sampling, sample storage and preparation of biomaterials for INAA in clinical medicine, occupational and environmental health. In: Harmonization of Health-Related Environmental Measurements Using Nuclear and Isotopic Techniques. IAEA, Vienna, 1997;pp 123-133
42. Zaichick V. Losses of chemical elements in biological samples under the dry ashing process. Trace Elements in Medicine (Moscow) 2004;5(3):17-2

43. Zaichick S, Zaichick $\mathrm{V}$. The $\mathrm{Br}, \mathrm{Fe}, \mathrm{Rb}, \mathrm{Sr}$, and $\mathrm{Zn}$ content and interrelation in intact and morphologic normal prostate tissue of adult men investigated by energy dispersive X-ray fluorescent analysis. X-Ray Spectrom 2011;40:464469

44. Zaichick S, Zaichick V. INAA applications in the age dynamics assessmen of $\mathrm{Br}, \mathrm{Ca}, \mathrm{Cl}, \mathrm{K}, \mathrm{Mg}, \mathrm{Mn}$, and $\mathrm{Na}$ content in the normal human prostate. J Radioanal Nucl Chem 2011;288:197-202

45. Zaichick $\mathrm{S}$, Zaichick V. The effect of age on $\mathrm{Ag}, \mathrm{Co}, \mathrm{Cr}, \mathrm{Fe}, \mathrm{Hg}, \mathrm{Sb}, \mathrm{Sc}, \mathrm{Se}$ and $\mathrm{Zn}$ contents in intact human prostate investigated by neutron activation analysis. Appl Radiat Isot 2011;69:827-833

46. Zaichick V, Nosenko S, Moskvina I. The effect of age on 12 chemical element contents in intact prostate of adult men investigated by inductively coupled plasma atomic emission spectrometry. Biol Trace Elem Res 2012;147:49-58

47. Zaichick $\mathrm{V}$, Zaichick $\mathrm{S}$. The effect of age on $\mathrm{Br}, \mathrm{Ca}, \mathrm{Cl}, \mathrm{K}, \mathrm{Mg}, \mathrm{Mn}$, and $\mathrm{Na}$ mass fraction in pediatric and young adult prostate glands investigated by neutron activation analysis. Appl Radiat Isot 2013;82:145-151

48. Zaichick V, Zaichick S. INAA application in the assessment of $\mathrm{Ag}, \mathrm{Co}, \mathrm{Cr}, \mathrm{Fe}$ $\mathrm{Hg}, \mathrm{Rb}, \mathrm{Sb}, \mathrm{Sc}, \mathrm{Se}$, and $\mathrm{Zn}$ mass fraction in pediatric and young adult prostate glands. J Radioanal Nucl Chem 2013;298:1559-1566

49. Zaichick V, Zaichick S. NAA-SLR and ICP-AES Application in the Assessment of Mass Fraction of 19 Chemical Elements in Pediatric and Young Adult Prostate Glands. Biol Trace Elem Res 2013;156:357-366

50. Korelo AM, Zaichick V. Software to optimize the multielement INAA of medical and environmental samples. In: Activation Analysis in Environment Protection. Join Institute of Nuclear Research, Dubna, Russia, pp 1993;326332

51. Zaichick S, Zaichick V. Relations of morphometric parameters to zinc content in paediatric and nonhyperplastic young adult prostate glands. Andrology 2013;1:139-146

52. Zaichick V, Zaichick S. Relations of bromine, iron, rubidium, strontium, and zinc content to morphometric parameters in pediatric and nonhyperplastic young adult prostate glands. Biol Trace Elem Res 2014;157:195-204

53. Zaichick V, Zaichick S. Relations of the neutron activation analysis data to morphometric parameters in pediatric and nonhyperplastic young adult prostate glands. Advances in Biomedical Science and Engineering 2014;1(1):26-42

54. Zaichick $\mathrm{V}$, Zaichick $\mathrm{S}$. Relations of the $\mathrm{Al}, \mathrm{B}, \mathrm{Ba}, \mathrm{Br}, \mathrm{Ca}, \mathrm{Cl}, \mathrm{Cu}, \mathrm{Fe}, \mathrm{K}, \mathrm{Li}$ $\mathrm{Mg}, \mathrm{Mn}, \mathrm{Na}, \mathrm{P}, \mathrm{S}, \mathrm{Si}, \mathrm{Sr}$, and $\mathrm{Zn}$ mass fractions to morphometric parameters in pediatric and nonhyperplastic young adult prostate glands. BioMetals 2014;27:333-348

55. Zaichick V, Zaichick $S$. The distribution of 54 trace elements including zinc in pediatric and nonhyperplastic young adult prostate gland tissues. Journal of Clinical and Laboratory Investigation Updates 2014;2(1):1-15

56. Zaichick V. The prostatic urethra as a Venturi effect urine-jet pump to drain prostatic fluid. Medical Hypotheses 2014;83:65-68

57. High KP. Nutritional strategies to boost immunity and prevent infection in elderly individuals. Clin Infect Dis 2001;33:1892-1900

58. Padro L, Benacer R, Foix S, Maestre E, Murillo S, Sanvicens E, Somoza D, Ngo J, Cervera P. Assessment of dietary adequacy for an elderly population based on a Mediterranean model. J Nutrit Health Aging 6:31-33

59. International Commission on Radiological P2002;rotection. Report No 23 of the Task Group on reference Man. Pergamon Press, Oxford. 1975

60. Iyengar GV, Kollmer WE, Bowen HGM. The Elemental Composition of Human Tissues and Body Fluids. A Compilation of Values for Adults. Verlag Chemie, Weinheim, 1978

61. Iyengar GV. Reevaluation of the trace element content in reference men Radiat Phys Chem 1998;51:545-560

62. Bozym RA, Chimienti F, Giblin LJ, Gross GW, Korichneva I, Li Y, Libert S, Maret W, Parviz M, Frederickson CJ, Thompson RB. Free zinc ions outside a narrow concentration range are toxic to a variety of cells in vitro. Exp Biol Med (Maywood) 2010;235:741-750

63. Holmes MD, Pollak MN, Willett WC, Hankinson SE. Dietary correlates of plasma insulin-like growth factor I and insulin-like growth factor binding protein 3 concentrations. Cancer Epidemiol Biomarkers Prev 2002;11:852-861

64. Prasad AS, Mantzoros CS, Beck FW, Hess JW, Brewer GJ. Zinc status and serum testosterone levels of healthy adults. Nutrition 1996;12:344-348

65. Leake A, Chrisholm GD, Busuttil A, Habib FK. Subcellular distribution of zinc in the benign and malignant human prostate: evidence for a direct zinc androgen interaction. Acta Endocrinol (Copenh) 1984;105:281-288

66. Schwartz MK. Role of trace elements in cancer. Cancer Res 1975;35:3481-3487

67. Matusik RJ, Kreis C, McNicol P, Sweetland R, Mullin C, Fleming WH, Dodd JG. Regulation of prostatic genes: role of androgens and zinc in gene expression. Biochem. Cell Biol 1986;64:601-607

68. Blok LJ, Grossmann ME, Perry JE, Tindall DJ. Characterization of an early growth response gene, which encodes a zinc finger transcription factor, potentially involved in cell cycle regulation. Mol Endocrinol 1995;9:1610-1620

69. Zezerov YeG. Hormonal and molecular-biological factors of prostate cancer pathogenesis. Voprosy Oncologii 2001;47(2):174-181

70. Truong-Tran AQ, Ho LH, Chai F, Zalewski PD. Cellular zinc fluxes and the regulation of apoptosis/gene-directed cell death. J Nutr 2000;130(5S 
Suppl):1459S-1466S

71. Kontargiris E, Vadalouka A, Ragos V, Kalfakakou V. Zinc inhibits apoptosis and maintains NEP downregulation, induced by Ropivacaine, in HaCaT cells. Biol Trace Elem Res 2012;150:460-466

72. Liang D, Yang M, Guo B, Cao J, Yang L, Guo X, Li Y, Gao Z. Zinc inhibits H2O2-induced MC3T3-E1 cells apoptosis via MAPK and PI3K/AKT pathways. Biol Trace Elem Res 2012;148:420-429

73. Zhang X, Liang D, Guo B, Yang L, Wang L, Ma J. Zinc inhibits high glucoseinduced apoptosis in peritoneal mesothelial cells. Biol Trace Elem Res 2012;150:424-432

74. Chua AC, Klopcic B, Lawrance IC, Olynyk JK, Trinder D. Iron: an emerging factor in colorectal carcinogenesis. World J Gastroenterol 2010;16:663-672

75. Bastide NM, Pierre FHF, Corpet DE. Heme Iron from Meat and Risk of Colorectal Cancer: A Meta-analysis and a Review of the Mechanisms Involved. Cancer Prev Res 2011;4:177-184

76. Toyokuni S. Mysterious link between iron overload and CDKN2A/2B. J Clin Biochem Nutr 2011;48:46-49. doi: 10.3164/jcbn.11-001FR

77. Cho M, Eze OP, Xu R. A Brief Review of the Controversial Role of Iron in Colorectal Carcinogenesis. J Clin Exp Pathol 2013;3:1-5. doi:10.4172/2161-
0681.1000137

78. Torti SV, Torti FM. Iron and cancer: more ore to be mined. Nature Reviews Cancer 2013;13:342-355. doi:10.1038/nrc3495

79. Hayes RB. The carcinogenicity of metals in humans. Cancer Causes Control 1997;8:371-385

80. Lison D, Boeck M De, Verougstraete V, Kirsch-Volders M. Update on the genotoxicity and carcinogenicity of cobalt compounds. Occup Environ Med 2001;58:619-625. doi:10.1136/oem.58.10.619

81. Magaye R, Zhao J, Bowman L, Ding M. Genotoxicity and carcinogenicity of cobalt-, nickel- and copper-based nanoparticles. Exp Ther Med 2012;4:551561

82. Michaud DS, Augustsson K, Rimm EB, Stampfer MJ, Willet WC, Giovannucci E. A prospective study on intake of animal products and risk of prostate cancer. Cancer Causes Control 2001;12:557-567

83. Gallus S, Foschi R, Negri E, Talamini R, Franceschi S, Montella M, Ramazzotti V, Tavani A, Dal Maso L, La Vecchia C. Dietary zinc and prostate cancer risk: a case-control study from Italy. Eur Urol 2007;52:1052-1056 